\title{
Student and Teacher Perceptions of Teaching Personal and Social Responsibility Implementation, Academic Performance and Gender Differences in Secondary Education
}

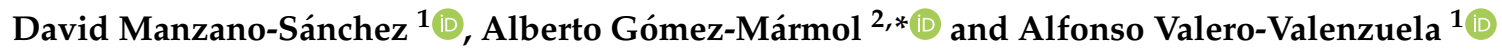 \\ 1 Faculty of Sports Sciences, University of Murcia, 30720 Murcia, Spain; david.manzano@um.es (D.M.-S.); \\ avalero@um.es (A.V.-V.) \\ 2 Faculty of Education, University of Murcia, 11, 30100 Murcia, Spain \\ * Correspondence: alberto.gomez1@um.es
}

Received: 9 May 2020; Accepted: 29 May 2020; Published: 4 June 2020

\begin{abstract}
The aim of this study was to determine how secondary education students and teachers perceive the implementation of the Teaching Personal and Social Responsibility model (TPSR), the relationship between TPSR and marks in physical education (PE), and potential differences with regard to gender. For this purpose, TPSR was implemented for seven months and on completion 121 students ( 48 girls) aged between 12 and 16 from the first and third grade of secondary education were asked to complete the TPSR perception questionnaire (ECVA-12) to determine their satisfaction with this methodology and the values the model promoted in pupils. Moreover, the participant teachers were also interviewed. Results showed positive student perceptions of the implemented methodology and its promotion of values, and significant differences in academic performance in PE in favor of males. Teachers valued this methodology very positively and considered that it would be useful with any kind of student. This paper suggests the importance of TPSR implementation for all teachers, regardless of their specialism, and considers that there may be potential in engaging other collectives such as families.
\end{abstract}

Keywords: Hellison; interviews; marks; personal and social responsibility; educational innovation

\section{Introduction}

Currently, society demands that formal education provides the tools to enable students to adapt themselves to the constant changes in their environment [1]. In order to achieve this, it is important to foster students' autonomy and self-sufficiency [2], improve the learning environment [3] and decrease teacher dependency through increasing co-operative work amongst classmates [4]. In addition, academic performance is also a main concern within education, especially how this can be affected by family variables $[5,6]$ or by the teaching methodology used by teachers; the latter considered by Hattie [7] as one of the most influential factors, particularly with regard to motivational development [8-12].

With regard to academic performance, López Guillamón and Clares-Clares [13] highlight the proliferation of research as a consequence of a growing interest within the scientific community. However, they also remark that this research trend focuses on subjects such as languages or maths, omitting others, for example, physical education (PE). Additionally, Gázquez et al. [14] analysed the relationship between violent school settings and academic performance. They concluded that lower marks are much more frequent amongst those students who are in violent environments. 
In order to achieve improvements in teaching, during the last few years, pedagogical models and education innovation projects have been developed $[15,16]$. In particular, the Teaching Personal and Social Responsibility model (TPSR) of Hellison [17] is one of the most important because it fosters better behavior from students in their social environments and teaches them responsibility for themselves and others. This model has been considered to have one of the strongest methodologies for developing values during the adolescence stage $[18,19]$, however, its main limitation is lack of time; implementation at school has been reduced to a few hours per week in relation to physical activity [20]. Consequently, Martinek and Hellison [21] have proposed that future research extends implementation of the TPSR model to the whole education context, with the common engagement of all teachers at every stage (primary and secondary education) in order to achieve an improvement in students' quality of life.

Regarding gender differences in the level of personal and social responsibility, the results of scientific research partially disagree. Thus, the research conducted by Sánchez-Alcaraz et al. [22] affirms that TPSR implementation increases responsibility levels in males and females, but that this increase is higher for both types of responsibility (personal and social) in males. However, other research has found significant changes only in personal responsibility [23] and without differences in social responsibility between boys and girls [24].

Latest trends in TPSR include the aim to innovate with the model through research that hybridizes it with the Sport Education Model (SEM) [25], with very positive results reported in the areas of social responsibility, violence, perceived competence and social relationships. Fernández et al. [26] hybridized TPSR with cooperative learning and concluded that TPSR is a highly suitable methodology for use in meeting the demands of the current education system as well as in developing social skills [27]. Moreover, Hortigüela et al. [28] implemented TPSR with university students from Spain, Costa Rica and Chile and found that those who intended to become teachers recognized its many pedagogical possibilities and intended to employ it. TPSR use may support the hypotheses of Vallerand [29] due to its capabilities in promoting responsibility and, subsequently, internal motivation. On this subject, Manzano and Valero [30] demonstrate that the satisfaction of basic psychological needs may trigger positive behaviors that result in an improvement of the classroom climate. In summary, the TPSR has been used in numerous settings (PE, after-school activities, ... ) with different participant profiles (middle class, at risk of exclusion, ... ) and with a great variety of activities related to physical activity [9]. In turn, the review by Pozo, Grao and Pérez [10] indicates that TPSR studies date back more than 40 years, confirming what was said by Caballero, Delgado and Escartí [9] when speaking that this model has been tested with very good results in different settings and in different environments, especially in risk populations.

The need for long-term implementation of TPSR and a statement of clear guidelines as to its appropriate development, make 'Continuous Professional Development' (CPD) [31] a crucial aspect in ensuring the success of teacher training and the obtainment of the expected results in students. One of the most valuable tools for CPD is systematic observation and, specifically for TPSR, Coulson, Irwin and Wright [32] suggest the use of the 'Tool for Assessment of Responsibility Education' (TARE) developed by Wright and Craig [33]. Hemphill, Templin and Wright [34] have considered this as suitable for increasing the methodological rigor of TPSR based research.

This investigation not only tackles the future role of TPRS, highlighted by Martinek and Hellison [21], who suggest the development of research that implements TPSR within longer time periods, but also the need to continue with the study of gender differences in personal and social responsibility levels, as highlighted by Manzano et al. [23]. Additionally, this research also assesses academic performance within PE, the subject where TPRS was founded. Therefore, the main goal of this research was to determine the perception of secondary education students and teachers on the implementation of TPSR, the relationship between TPSR and grades in PE, and potential differences with regard to gender. 


\section{Materials and Methods}

\subsection{Design}

Following Anguera, Camerino and Castañer [35], a 'mixed method' approach of data triangulation was applied, using qualitative instruments (observational analysis of the implementation of the TPSR model and semi-structured interviews) and quantitative (with questionnaires), in addition to continuous training and advice for teachers (CPD). It is, therefore, a longitudinal, quasi-experimental, descriptive, and relational study [36].

Informed consent (for confidential data processing, participation in the study and filming of the sessions) was obtained from both the students and their parents or legal guardians, via a letter of introduction from the secondary education center. In addition the approval of the Ethics Committee of the University of Murcia (1685/2017) was obtained. The intervention program lasted nine months, from the beginning of the first academic trimester and throughout the second and third trimester. The content was selected according to current educational laws [37].

\subsection{Participants}

Participants were selected for accessibility and convenience [38]. The sample consisted of two secondary school PE teachers and a total of 121 students after the inclusion criteria was applied: (a) Have completed all the test scales, (b) have completed both the pre-test and the post-test, (c) have completed at least $90 \%$ of the items, and (d) the elimination of atypical cases after calculating the Mahalanobis distance. Among the 121 students there were 73 boys and 48 girls, aged between 12 and 16 years old, belonging to the first and third years of secondary education and with a medium socioeconomic level. None of the students had previous experience with TPSR.

\subsection{Instruments}

Questionnaire for evaluating the Personal and Social Responsibility model for promoting values in students (ECVA-12): This is a questionnaire validated by Rodríguez, Manzano and Valero [39], composed of 12 items that are grouped into two factors, each preceded by the premise 'Compared to the previous way of teaching in my teacher's classes, the responsibility model has caused...'. The first factor is 'satisfaction with the methodology' (items 2, 3, 4, 5, 6, 7, value of $\alpha=0.914$ ), for example item 2, 'I experienced a better climate of respect in class'. The second factor is 'promotion of values' (items 1,8 , $910,11,12$, value of $\alpha=0.820$ ), for example, item 8 'I applied what I have learned in class to situations outside the classroom, such as organizing my homework'.

Academic performance: To assess academic performance, the grades obtained in PE during the three quarters were analyzed.

Observation of the teaching intervention: In order to ensure that the teaching intervention conformed to the methodological guidelines established by the TPSR model, the TARE instrument was used [33]; this has been proven to be a highly reliable tool appropriate for this purpose [34].

Interviews: The interviews were conducted ad-hoc by the main researchers, selecting in consensus three questions in a semi-structured way with open questions for the two participating teachers, specifically the questions were: (1) Did you like more or less the way of teaching/learning with the TPSR than the traditional way? (2) Would you like to be able to keep using/receiving the responsibility model-based methodology in future courses? (3) Do you believe the responsibility model-based methodology has served to improve values such as respect, effort, autonomy or class participation?

\subsection{Process}

Firstly, the research design was submitted to the criteria of the Ethics Committee of the University of Murcia (1685/2017) to ensure that it complied with the guidelines of the Helsinki Declaration on research ethics. After obtaining the approval of this institution, the information sheets were 
administered to the participating center to confirm their willingness to participate in the study, and to collect informed consent from parents or guardians.

According to Lee and Choi [40], the implementation of any educational program requires specific teacher training. For this purpose, the teachers responsible for the implementation of TPRS were trained in the model through a two-phase approach, firstly, a five hour course on model theory and practice, in which they were taught how to design the classroom climate according to the model and were provided with global and specific strategies for the development of responsibility. In addition, they received a 'model guide' so that they could review the various strategies. Secondly, they received continuous training; during the implementation of the program, the main researcher had continuous contact (at least weekly) with the teachers. The intervention program followed a work progression through the first four levels [41], with level five considered from the beginning with the aim of transferring it to the lives of the students.

Based on the proposal of Hellison [17], the structure of the sessions was divided into five phases: (1) Relation time: the teachers interacted with their students to create links with them, (2) awareness talk: the teachers presented the academic objectives of the session and values according to the level of the responsibility model, (3) physical activity plan: where most of the practical class was collected, integrating responsibility strategies in the various tasks, (4) group meetings, and (5) reflection time. At the end of each session, teachers and students shared their perceptions about responsibility and individual behaviors, both of the class collective and the teacher's performance, indicating this using the thumb technique. This technique consists of lifting the thumb upwards (positive evaluation), to the side (neutral) or downwards (negative evaluation). Teachers used general strategies to implement TPRS (e.g., assigning tasks, providing opportunities for success, and defining roles) and specific strategies (e.g., reciprocal teaching, co-operative groups, and the personal work plan). Similarly, strategies were also used to resolve individual disputes (e.g., five clean days) and collective disputes (e.g., grandmother's law). In addition, at the end of each session, teachers also had to self-assess their performance using the TARE [33] to encourage reflection on the implementation of TPSR, answering in a dichotomous (yes/no) scale.

During the implementation of the model, teachers were followed by experts in TPSR to ensure that the methodology being applied corresponded to what was expected. Thus, on a weekly basis, contact was maintained with the teachers to resolve any doubts they may have had. Sessions were regularly filmed and analyzed by experts. These experts also received training which occurred in the following sequence: (1) Explanation and description of the methodology of the TPSR model, (2) explanation and clarification of the meaning of each of the categories of the TARE instrument, (3) visualization of a complete class of the TPSR program using TARE, (4) pooling the results of observations in order to combine criteria in the categories and verify that both interpreted the category system in the same way, and (5) when there was a minimum agreement of $80 \%$ between the observers, it was considered that they were ready to begin to register formally for the present investigation.

In all the filmed sessions, an adjustment to the methodology of over $80 \%$ was considered by Escartí et al. [41] as appropriate to ensure that the application of the methodology was completed correctly. After the analysis process of each session, the teachers received feedback comments to enable them to modify different aspects as necessary. In this way, different strategies (training seminars, video analysis, feedback loops, and question resolution) were used to provide correct guidance and support before and throughout the research project [42]. Most sessions had $80 \%$ agreement or over; where it was less than $80 \%$, feedback was given to the teacher in order to improve future sessions and the teacher had to record the next session. This situation happened twice (at the beginning of the study in the first month) and in the second session, the teachers in this situation achieved over $80 \%$.

\subsection{Analysis}

The statistical treatment of the collected data was performed using IBM SPSS 24.0 software, as well as Atlas.ti 7.5 for the analysis of the teachers' interviews. The reliability of the instrument was initially 
analyzed by calculating its internal consistency, using the Cronbach's Alpha test. The normality of the distribution of the data was then verified using a k-s test and chi-square analysis. All variables presented a non-normal distribution, so non-parametric procedures were used for their assessment (Mann-Whitney's U and Kendall's Tau-B bivariate correlations).

\section{Results}

The correlation analysis between methodology satisfaction, perception of the promotion of values and grades, reflect the absence of statistically specific correlations with this last variable. However, there is a correlation between general satisfaction with the TPSR model and perception of the promotion of values, as can be seen in Table 1 .

Table 1. Correlation between satisfaction with the Teaching Personal and Social Responsibility model (TPSR) and grades in PE.

\begin{tabular}{cccccccc}
\hline & Range & M & SD & $\mathbf{1}$ & $\mathbf{2}$ & $\mathbf{3}$ \\
\hline 1. & Methodology satisfaction & $1-5$ & 3.87 & 0.98 & $\mathrm{x}$ & $0.816^{* *}$ & 0.062 \\
2. & Promotion of values & $1-5$ & 3.83 & 0.73 & & $\mathrm{x}$ & 0.072 \\
3. & Grades & $1-10$ & 7.45 & 1.02 & & & $\mathrm{x}$ \\
\hline \multicolumn{7}{c}{ Note: $p<0.05=^{*}, p<0.01={ }^{* *} ; \mathrm{M}=$ Mean; SD $=$ Standard Deviation. }
\end{tabular}

Table 2 shows student perceptions of TPSR and their grades, and the possible differences between the genders are analyzed. The results do not show significant differences either in methodology satisfaction or in the perception of the promotion of values, although there are differences in the grades, which are higher in boys than in girls.

Table 2. Assessment of the Teaching Personal and Social Responsibility model (TPSR) by students, grades in PE and gender differences.

\begin{tabular}{cccccccc}
\hline & \multicolumn{2}{c}{ Male } & \multicolumn{2}{c}{ Female } & \multicolumn{3}{c}{ Total } \\
\cline { 2 - 8 } & $\mathbf{M}$ & SD & M & SD & M & SD & $p$ \\
\hline Methodology satisfaction & 3.87 & 0.98 & 3.93 & 0.97 & 3.89 & 0.97 & 0.736 \\
Promotion of values & 3.83 & 0.73 & 4.03 & 0.72 & 3.91 & 0.73 & 0.113 \\
Grades & 7.45 & 1.02 & 7.19 & 0.94 & 7.35 & 0.99 & $0.031^{*}$ \\
\hline
\end{tabular}

Note: $p<0.05={ }^{*} ; \mathrm{M}=$ Mean; $\mathrm{SD}=$ Standard Deviation.

Alternately, interviews with teachers show a favorable opinion towards TPSR. When they compare it with the traditional methodology, they report that:

'Before, I thought my students enjoyed the lessons, but now I really enjoy myself, I have a new way of teaching that undoubtedly allows me to develop better with my students' (Teacher A).

'I thought it would be a radical change, but as Antonio says, at the end it is not more complex than the teaching I was doing before' (Teacher B).

Furthermore, this assessment is not restricted to the limits of this research, as the will to continue using TPSR in future years is inferred. In this regard, the teachers pointed out that:

'Last year I already implemented it [TPSR] in a different school and this year I wanted to venture into this new center. Without a doubt it has been a success, it is independent of whether the students are better or more mischievous, it works with everyone. Next year it will continue to be part of my methodology' (Teacher A).

'I don't have much to add, I totally agree' (Teacher B). 
We also analyzed whether the teachers perceived that TPSR had resulted in an improvement of values in their students. In this regard, they identified that amongst the effects of the model it was possible to distinguish comprehensive student training, as shown in the following interview fragment regarding values within TPSR (do you believe that the methodology of the responsibility model has served to improve values such as respect, effort, autonomy or class participation?):

'Yes, it is what can most be concluded with the model [TPSR improves values such as respect, effort, autonomy or participation in class], although being such important values, the need to transfer that to other groups of great influence like families and the search for more colleagues to participate-as I think they are doing in other centers - would be a very good strategy' (Teacher A)

'It is, without any doubt, the most you can work with the model' (Teacher B).

\section{Discussion}

The main goal of this research was to determine how secondary education students and teachers perceive the implementation of TPSR, how TPSR is related to grades in PE and potential differences with regards to gender. It is noteworthy that we found no significant differences between boys and girls; this is contradictory to the significant differences found by Sánchez-Alcaraz et al. [22], the partial differences found by Carbonero et al. [24], and to Manzano et al. [23] where the perception of boys was more positive compared to that of girls, both in personal and social responsibility, or at least in personal responsibility. In this respect, in our research, all the teachers were of the same gender (male), and, despite the fact that this characteristic may be decisive for the results of the model, like Moreno et al. [43] and Villena [44], we found no differences between the students.

Alternately, the assessment of methodology satisfaction with TPSR obtained an average score of 3.89 , very similar to the promotion of values dimension, which was 3.91; in short, levels that reflect that the perception of the students was quite positive. In addition, all items had a rating above 3.60, with the worst rating being 'I experienced a better classroom climate', and the best 'I respected and cared for the equipment' with 3.60 and 4.30 respectively. This could be because the first pillar of the model is the 'respect' level and changes in the classroom climate are more complex to achieve. These results in student satisfaction can be compared to those of Caballero [11] with vocational training students, where the interviews indicated a positive perception of the TPSR both in their personal and social development and in their knowledge acquisition. Furthermore, it must be worked throughout the course and from a pedagogical perspective, with the involvement of a wide range of agents such as the remainder of the teachers, the family and society in general [45].

Regarding the grades, the result show significant differences between the genders, with higher academic performance in PE in boys compared to girls. It should be noted that the meta-analysis carried out by Voyer and Voyer [46] concludes that girls tend to achieve better grades than boys in all subjects. These differences, according to Balkis and Duru [47], may be due to the greater male tendency to procrastinate on issues related to their study as well as to their lower academic life satisfaction, something that does not conform to our study, probably due to the analysis of grades in PE against a whole subjects assessment.

Regarding the perception of teachers, it should be noted that, according to the recent systematic review of TPSR carried out by Sánchez-Alcaraz et al. [48], most empirical research has been focused on analyzing the effects of the intervention on students using predominantly quantitative instruments. This study represents an advance, not only through the use of qualitative methodologies such as interviews but, with the innovative characteristic of conducting them on the perceptions of the students and the teachers.

In accordance with research that has analyzed teachers' perception of TPSR regarding their instructional training, such as Ibaibarriaga and Tejero-González [49], we found that teachers prefer training courses that are extended over time rather than intensive courses such as those of Sánchez-Alcaraz et al. [22] and Escartí et al. [50], with short sessions orientated to practice; this 
last consideration coinciding with the conclusions of Escartí et al. [41]. More specifically, the teachers involved in Sánchez-Alcaraz et al. [45] did indicate that, compared to the former methodology, the TPSR could be more difficult to implement in some contexts, especially those in which there are no rules or regulation, such as body language. Teachers interviewed in this study did not make distinctions in content, affirming, in a simpler way, that this methodology 'allows them to cope better with students'.

Regarding the will to continue implementation of the model-based program later, a positive predisposition is shown, conforming with the results of Sánchez-Alcaraz et al. [45], although this research indicates that it 'works with everyone [students]' while Kallusky [51] and Martinek, Schilling and Hellison [52] noted that the model was more effective in those more disruptive students. In this sense, in connection with the perception of the effects on the students, this research has highlighted 'the need for the involvement of several highly influential groups such as the family ( ... ) and more colleagues [teachers] who participate'. Although the figure of the teacher is considered in different investigations as essential in this duty [41,53], other studies recognize the importance of teamwork in which various agents are involved, such as the family [54].

Regarding the limitations of this study, we suggest the possibility that more teachers should participate, both women and men and, in addition, based on what was also reported by the participants in this research, not only PE teachers, but also those from other subjects. Another limitation is due to the sample of participants (two PE teachers) as well as their selection because it was for accessibility, taking into account that one of them had already applied the TPSR methodology. On the other hand, it would have been interesting to contrast the ECVA-12 questionnaire in other subjects in order to analyze the impact that it might have on the acquisition of values and the opinion of the students. Finally, the analysis of the intervention sessions with TARE was done with the intention of evaluating the appropriateness of responsibility strategies, they were not compiled to analyze them together after the intervention, but were only analyzed at the time of verifying the specific session if teachers completed at least the $80 \%$ of the strategies correctly.

Additionally, as a future line of research, families are considered as a source of information to assess the real transfer of the effects of the implementation of TPSR to the context of daily life, expanding the study to other settings as it has suggested by Carreres [12]. Another suggestion from the same author, would be the TPSR application over several terms or academic years during the adolescence stage, to see if the learning and in this case, satisfaction with the TPSR is maintained over the years.

\section{Conclusions}

Firstly, students positively valued both the methodology used and the promotion of values enabled by TPSR, there being a clear relationship between both categories. These positive results are also contrasted by the other part of the teaching-learning process, where teachers indicated their assessment was also very positive, highlighting the functionality of this methodology with all types of students and the importance of teamwork by teachers and other social agents such as the family.

Secondly, the academic performance in PE for male students was higher than that achieved by girls, finding no differences in the assessment they have regarding the methodology, in terms of satisfaction, neither in the achievement of values.

Author Contributions: Conceptualization, D.M.-S., A.G.-M., and A.V.-V.; methodology, D.M.-S. and A.V.-V.; formal analysis, D.M.-S.; investigation, D.M.-S., A.G.-M. and A.V.-V.; data curation, D.M.-S.; writing-original draft preparation, D.M.-S. and A.V.-V.; writing-review and editing, D.M.-S., A.G.-M. and A.V.-V.; supervision, A.G.-M. and A.V.-V. All authors have read and agreed to the published version of the manuscript.

Funding: This research received no external funding.

Conflicts of Interest: The authors declare no conflict of interests. 


\section{References}

1. Oriol, X.; Amutio, A.; Mendoza, M.; Da Costa, S.; Miranda, R. Emotional creativity as predictor of intrinsic motivation and academic engagement in university students: The mediating role of positive emotions. Front. Psychol. 2016, 7, 1-9. [CrossRef]

2. Schiefelbein, E.; Schiefelbein, P. Evolution of the evaluation processes of the educational system 1950-2008. Revista Iberoamericana de Evaluación Educativa 2016, 1, 45-50.

3. Legault, L.; Inzlicht, M. Self-determination, self-regulation and the brain: Autonomy improves performance by enhancing neuroaffective responsiveness to self-regulation failure. J. Personal. Soc. Psychol. 2013, 105, 123-138. [CrossRef] [PubMed]

4. Walkey, F.; McClure, J.; Meyer, L.; Weir, K. Low expectations equal no expectations: Aspirations, motivation and achievement in secondary school. Contemp. Educ. Psychol. 2013, 38, 306-315. [CrossRef]

5. Menacho, C.H. Predicción del rendimiento académico aplicando técnicas de minería de datos. Anales Científicos 2017, 78, 26-33. [CrossRef]

6. Pérez, C.N.; Betancort, M.; Cabrera, L. Family influences in academic achievement. A study of the Canary Islands. Rev. Int. Sociol. 2013, 71, 169-187. [CrossRef]

7. Hattie, J. Visible Learning for Teachers. Maximizing Impact on Learning; Routledge: London, UK; Taylor \& Francis Group: New York, NY, USA, 2012.

8. Beltrán, I. Un análisis empírico de los determinantes de la implicación académica en estudiantado universitario. Revista Tecnología Ciencia y Educación 2019, 12, 47-64.

9. Caballero, P.; Delgado, M.A.; Escartí, A. Analysis of Teaching Personal and Social Responsibility model-based programmes applied in USA and Spain. J. Hum. Sport Exerc. 2014, 8, 427-441. [CrossRef]

10. Pozo, P.; Grao, A.; Pérez, R. Teaching personal and social responsibility model-based programs in physical education: A systematic review. Eur. Phys. Educ. Rev. 2016, 24, 56-75. [CrossRef]

11. Caballero, P. Vocational education students' perceptions about the effects of a positive development program (Responsibility Hellison's Model). J. Sport Health Res. 2015, 7, 113-126.

12. Carreres, F. Efectos, En Los Adolescentes, De un Programa de Responsabilidad Personal y Social a Través Del Deporte Extraescolar. Ph.D. Thesis, University of Alicante, Alicante, Spain, 2014. Available online: http://rua.ua.es/dspace/bitstream/10045/37220/1/tesis_federico_carreres_posada.pdf (accessed on 5 May 2020).

13. López Guillamón, A.; Clares-Clares, M.E. Rendimiento académico en el aula de música en Educación Primaria. In Investigación E Innovación Educativa En El Siglo XXI; Gómez-Mármol, A., De Pro, C., Eds.; Wanceulen: Granada, Spain, 2019; pp. 315-321.

14. Gázquez, J.J.; Molero, M.; Pérez-Fuentes, M.C.; Simón, M.M.; Barragán, A.B.; Martos, A. Investigación En el Ámbito Escolar: Un Acercamiento Multidimensional A Las Variables Psicológicas Y Educativas; Grupo Editorial Universitario (GEU Editorial): Granada, Spain, 2006.

15. Luna Delgado, D. Innovative teaching approaches in History: A study based on four central themes. Panta Rei Revista Digital de Ciencia y Didáctica de la Historia 2019, 161-181. [CrossRef]

16. Menéndez, J.I.; Fernández-Río, J. Social responsibility, basic psychological needs, intrinsic motivation, and friendship goals in physical education. Retos 2016, 32, 134-139.

17. Hellison, D. Goals and Strategies for Teaching Physical Education; Human Kinetics Publishers: Champaign, IL, USA, 2011.

18. Escartí, A.; Pascual, C.; Gutiérrez, M. Personal and Social Responsibility through Physical Activity and Sport; Graó: Barcelona, Spain, 2005.

19. Gómez-Mármol, A.; Sánchez-Alcaraz, B.J.; De la Cruz, E.; Valero-Valenzuela, A.; González-Víllora, S. Personal and social responsibility development through sport participation in youth scholars. J. Phys. Educ. Sport 2017, 17, 775-782.

20. Llopis-Goig, R.; Escartí, A.; Pascual, C.; Gutiérrez, M.; Marín, D. Strengths, difficulties and improvable aspects in the application of a Personal and Social Responsibility Programme in Physical Education: An evaluation based on the implementers' perceptions. Cult. Y Educ. 2011, 23, 445-461. [CrossRef]

21. Martinek, T.; Hellison, D. Teaching personal and social responsibility: Past, present and future. J. Phys. Educ. Recreat. Danc. 2016, 87, 9-13. [CrossRef]

22. Sánchez-Alcaraz, B.J.; Gómez-Mármol, A.; Valero, A.; De la Cruz, E. Application of a program to improve personal and social responsibility in Physical Education classes. Mot. Eur. J. Hum. Mov. 2013, 30, 121-129. 
23. Manzano, D.; Valero, A.; Conde, A.; Ming, C. Applying the personal and social responsibility model-based program: Differences according to gender between basic psychological needs, motivation, life satisfaction and intention to be physically active. Int. J. Environ. Res. Public Health 2019, 16, 2326. [CrossRef]

24. Carbonero, M.A.; Martín-Antón, L.J.; Monsalvo, E.; Valdivieso, J.A. School performance and personal attitudes and social responsibility in preadolescent students. Anales de Psicología 2015, 31, 990-999. [CrossRef]

25. Menéndez, J.I.; Fernández-Río, J. Violence, responsibility, friendship and basic psychological needs: Effects of a sports education and personal and social responsibility program. Revista De Psicodidactica 2016, 21, 245-260. [CrossRef]

26. Fernández, J.; Calderón, A.; Hortigüela, D.; Pérez, A.; Aznar, M. Pedagogical models in physical education: Theoretical and practical considerations for teachers. Revista Espanola de Educacion Fisica y Deportes 2016, 413, 55-75.

27. Merino-Barrero, J.A.; Valero-Valenzuela, A.; Belando-Pedreño, N. The personal and social responsibility model: Variables associated with its implementation. EmasF Revista Digital de Educación Física 2017, 49, 60-77.

28. Hortigüela, D.; Fernández-Río, J.; González-Calvo, G.; Pérez-Pueyo, A. Comparing effects of a TPSR training program on prospective physical education teachers' social goals, discipline and autonomy strategies in Spain, Chile and Costa Rica. Phys. Educ. Sport Pedagog. 2019, 24, 220-232. [CrossRef]

29. Vallerand, R.J. Toward a hierarchical model of intrinsic and extrinsic motivation. Adv. Exp. Soc. Psychol. 1997, 29, 271-360. [CrossRef]

30. Manzano, D.; Valero, A. Implementation of a model-based programme to promote personal and social responsibility and its effects on motivation, prosocial behaviours, violence and classroom climate in primary and secondary education. Int. J. Environ. Res. Public Health 2019, 16, 4259. [CrossRef]

31. Darling-Hammond, L.; Richardson, N. Research review/teacher learning: What matters. Educ. Leadersh. 2009, 66, 46-53.

32. Coulson, C.; Irwin, C.; Wright, P.M. Applying Hellison's responsibility model in a residential treatment facility. Agora Phys. Educ. Sport 2012, 14, 38-54.

33. Wright, P.M.; Craig, M.W. Tool for assessing responsibility-based education (TARE): Instrument development, content validity, and inter-rater reliability. Meas. Phys. Educ. Exerc. Sci. 2011, 15, 204-219. [CrossRef]

34. Hemphill, M.A.; Templin, T.J.; Wright, P.M. Implementation and outcomes of a responsibility-based continuing professional development protocol in physical education. Sport Educ. Soc. 2015, 20, 398-419. [CrossRef]

35. Anguera, M.T.; Camerino, O.; Castañer, M. Mixed Methods Research in the Movement Sciences: Case Studies in Sport, Physical Education and Dance; Routledge: London, UK, 2012.

36. Thomas, J.R.; Nelson, J.K. Research Methods in Physical Activity; Paidotribo: Barcelona, Spain, 2007.

37. Ley Orgánica 8/2013, de 9 de Diciembre, Para la Mejora de la Calidad Educativa. Available online: https: //www.boe.es/buscar/pdf/2013/BOE-A-2013-12886-consolidado.pdf (accessed on 5 May 2020). (In Spanish)

38. Latorre, A.; Del Rincón, D.; Arnal, J. Methodological Bases of Educational Research; Experiencia: Barcelona, Spain, 2003.

39. Rodríguez, I.; Manzano, D.; Valero, A. Design and validation of the comparative questionnaire of the previous methodology with the model of personal and social responsibility in schoolchildren. Cuadernos de Psicología del Deporte. in press.

40. Lee, O.; Choi, E. The influence of professional development on teachers' implementation of the teaching personal and social responsibility model. J. Teach. Phys. Educ. 2015, 34, 603-625. [CrossRef]

41. Escartí, A.; Gutiérrez, M.; Pascual, C.; Wright, P.M. Observation of the strategies that physical education teachers use to teach personal and social responsibility. Revista de Psicología del Deporte 2013, 22, 159-166.

42. Braithwaite, R.E.; Spray, C.M.; Warburton, V.E. Motivational climate interventions in physical education: A meta-analysis. Psychol. Sport Exerc. 2011, 12, 628-638. [CrossRef]

43. Moreno, J.A.; Sánchez, M.; Rodríguez, D.; Prieto, M.; Mula, C. Puede el comportamiento del profesor influir en la valoración que el alumno realiza de la Educación Física. In III Congreso de Educación Física e Interculturalidad; Díaz, A., Moreno, J.A., Rodríguez, P.L., Eds.; Consejería de Educación: Murcia, Spain, 2002.

44. Villena, M.D. Incidence of the Attitudes and Personality of the Teacher in the Social Behavior of the Students: Social Competence and Class Social Climate. Ph.D. Thesis, University of Granada, Granada, Spain, 2016. 
45. Sánchez-Alcaraz, B.J.; Cañadas, M.; Valero, A.; Gómez-Mármol, A.; Funes, A. Results, difficulties and improvements in the model of personal and social responsibility. Apunts Educació Física i Esports 2019, 136, 62-82. [CrossRef]

46. Voyer, D.; Voyer, D.S. Gender differences in scholastic achievement: A meta-analysis. Psychol. Bull. 2014, 140, 1174-1204. [CrossRef]

47. Balkis, M.; Duru, E. Gender differences in the relationship between academic procrastination, satisfaction with academic life and academic performance. Electron. J. Res. Educ. Psychol. 2017, 15, 105-125. [CrossRef]

48. Sánchez-Alcaraz, B.J.; Courel, J.; Sánchez, C.; Valero, A.; Gómez-Mármol, A. Personal and social responsibility model through sports: A bibliographic review. Retos 2020, 37, 755-762.

49. Ibaibarriaga, A.; Tejero-González, C.M. What are professors'opinion when they receive training on the Personal and Social Responsibility Model? A study based on focus group. Retos 2020, 37, 115-122.

50. Escartí, A.; Gutiérrez, M.; Pascual, C.; Llopis-Goig, R. Implementation of the personal and social responsibility model to improve self-efficacy during physical education classes for primary school children. Int. J. Psychol. Psychol. Ther. 2010, 10, 387-402.

51. Kallusky, J. In-school programs. In Youth Development and Physical Activity: Linking Universities and Communities; Hellison, D., Cutforth, N., Kallusky, J., Martinek, T., Parker, M., Stiehl, J., Eds.; Human Kinetics: Champaign, IL, USA, 2000.

52. Martinek, T.; Schilling, T.; Hellison, D. Transferring personal and social responsibility of underserved youth to the classroom. Urban Rev. 2001, 33, 29-45. [CrossRef]

53. Walsh, D.; Ozaeta, J.; Wright, P.M. Transference of responsibility model goals to the school environment: Exploring the impact of a coaching club program. Phys. Educ. Sport Pedagog. 2010, 15, 15-28. [CrossRef]

54. Wright, P.M.; Jacobs, J.M.; Howell, S.M.; McLoughlin, G.M. Implementation and perceived benefits of an after-school soccer program designed to promote social and emotional learning: A multiple case study. J. Amat. Sport 2020, 6, 125-145. [CrossRef]

(C) 2020 by the authors. Licensee MDPI, Basel, Switzerland. This article is an open access article distributed under the terms and conditions of the Creative Commons Attribution (CC BY) license (http://creativecommons.org/licenses/by/4.0/). 